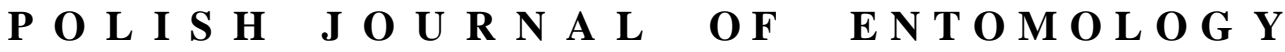

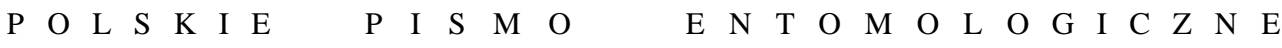

VOL. 85: $355-363$

Lublin

30 September 2016

DOI: $10.1515 /$ pjen-2016-0020

\section{Nemophora prodigellus (ZELLER, 1853) (Lepidoptera, Adelidae): the first definite record in Poland, with comments on the protection of its habitat}

\author{
ADAM MALKIEWICZ* \\ Department of Invertebrate Biology, Evolution and Conservation, \\ Institute of Environmental Biology, Faculty of Biological Science, University of Wrocław, \\ Przybyszewskiego 65, PL-51-148 Wrocław, Poland
}

\begin{abstract}
Nemophora prodigellus has been definitely recorded in Poland for the first time. Its habitus, i.e. wings, head and genitalia, are described and photographed. The moth's distribution, biology and habitat requirements are commented on. Problems involving the management of open protected habitats and their plant and animal species are discussed.
\end{abstract}

KEY WORDS: Lepidoptera, Adelidae, new record, rediscovery, distribution, Poland.

\section{INTRODUCTION}

Until a few years ago, the Adelidae was one of the faunistically most neglected families of micro-moths, even though the monograph by RAZOWSKI (1978) gives a good overview of the family. Nonetheless, some species may still be awaiting discovery or rediscovery in those parts of the country that to date have been less intensively explored (all the western provinces). Moreover, being concealed in their early developmental stages and strictly associated with their hostplants (especially the females), the imagines rarely come to light. According to the recent checklist by BUSZKO \& NOWACKI (2000), 28 adelid species have been found in Poland, but knowledge of their current distribution in the country is far from complete. One of them has not been recorded since 1960 and six have recent records in

\footnotetext{
* Corresponding author: adam.malkiewicz@uwr.edu.pl
} 
only one province. Moreover, recording in the south-western provinces of the country has been badly neglected in recent years. In the provinces of Lower Silesia and Opole only four species were recorded after 1960, whereas there were historical records of 22 species from these two regions.

One such species, expected to be rediscovered after several decades, is Nemophora prodigellus (ZELLER, 1853) (syn. auricellus RAGONOT, 1874). It was recorded once (1 ex.) in Rzeczanów [prev. Rzyczanów] near Rytro (Nowy Sącz district) around 1900. (SCHILLE 1902 [as auricellus RAGONOT, 1874]; SCHILLE 1914-1915; SCHILLE \& ROMANISZYN 1931; RAZOWSKI 1978 [as auricella RAGONOT, 1874]). This specimen was not studied in detail, because it was probably lost during the First World War, together with almost the entire early collection of Fryderyk SCHILLE. In those days butterflies and moths were identified solely according to their external morphology, so one cannot be sure whether this specimen was indeed correctly identified. This doubt has arisen because there is another species Nemophora fasciella (FABRICIUS, 1775) - that is very similar in its habitus to $N$. prodigellus. In many cases, therefore, dissection of the genitalia is the only reliable method of telling them apart.

\section{MATERIAL ANALYSED}

Nemophora prodigellus (ZELLER, 1853)

[syn.: auricellus RAGONOT, 1874; splendidus STAUDINGER, 1880; prodigellus sensu HEINEMANN, 1870]

Sulistrowiczki: N5050'35”, E16 43'44” (Ślężański Landscape Park - UTM: XS23), 21 VII 2012, 1 §ิ, 1 q, (Fig. 1); on flowers of Stachys officinalis L., leg. A. MALKIEWICZ; coll. A. MALKIEWICZ.

The moths were collected on a hot, sunny afternoon on a flowery meadow covering a gentle, north-west facing slope. They were nectaring on flowers of Stachys officinalis L. This meadow is situated just to the north of the "Łąka Sulistrowicka" Nature Reserve, beyond the boundary of the "Masyw Ślęży" Special Area of Conservation (PLH020040). 

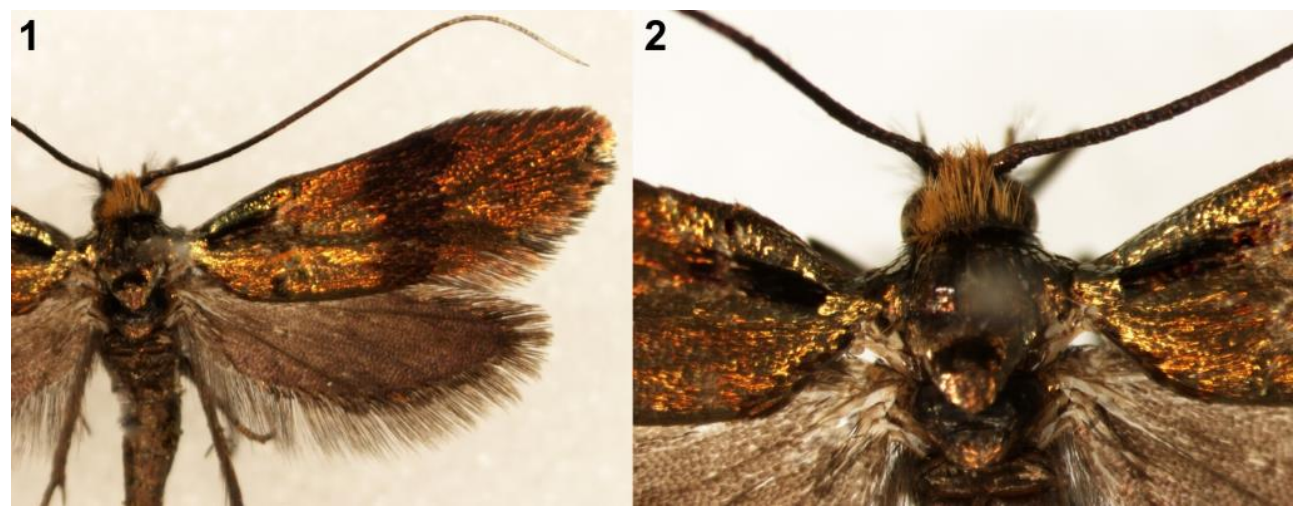

Fig. 1, 2. Nemophora prodigellus - female (Sulistrowiczki); habitus - 1. Right side wings (dorsal), 2. head, thorax and fore wing bases. Photo A. MALKIEWICZ.
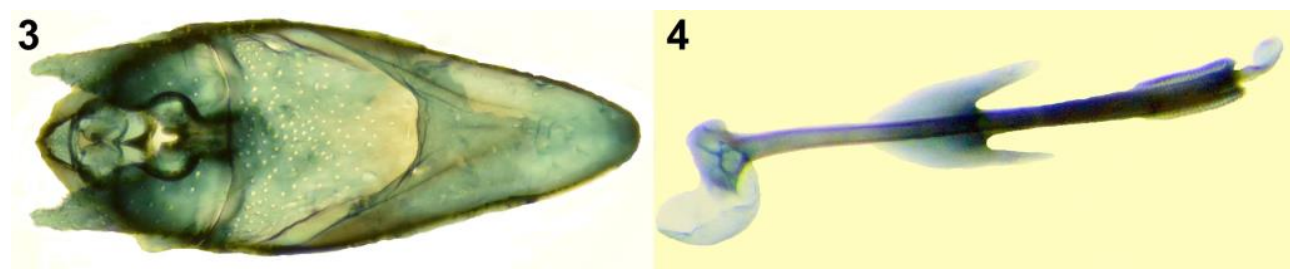

Fig. 3, 4. Nemophora prodigellus - male genitalia (Sulistrowiczki) - 3. Ventral view, 4. aedeagus and juxta. Photo A. MALKIEWICZ.

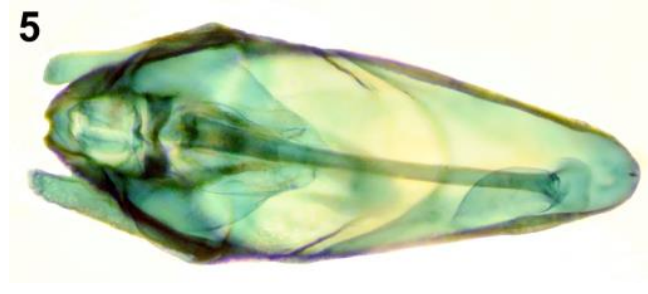

Fig. 5. Nemophora fasciella male genitalia (Koźlice ad Lubin) - Ventral view. Photo A. MALKIEWICZ.

\section{DIFFERENTIAL DIAGNOSIS}

This species is included and characterized in the relevant Key to the Identification of the Insects of Poland (WoJTUSIAK 1972) and in the monograph on the Adeloidea of Poland by RAZOWSKI (1978). Both provide a differential diagnosis with illustrations of the adult moth (male) and the genitalia of both sexes. The species most often compared with $N$. prodigellus is the above-mentioned $N$. fasciella, the habitus of which differs only slightly in the colour and sheen of both pairs of wings. Both sexes of $N$. prodigellus differ in the distinct black spot at the base of the R stem (Fig. 2), which N. fasciella does not bear; in the 
rare cases when the latter does have this spot, it is much reduced (KozLov 2004). In males of $N$. prodigellus the hind wing is paler without any purple sheen, and with a slightly darker apex. The sheen on the outer part of the fore wing is reddish-brown (in the female) but coppery-purple in $N$. fasciella. The basal areas of the wings in both species have a greenish-yellow sheen. In addition, the long scales on the head of the female are rustyyellow in $N$. prodigellus (Fig. 2) and yellow in N. fasciella. In the male genitalia of $N$. prodigellus (Fig. 3) the uncus is distinctly bluntly convex with three tubercles at the tip, whereas in N. fasciella it is concave (Fig. 5). There is a distinct break in the line in the middle of the outer edge of the valva. The aedeagus in N. prodigellus is thin and shorter, with blunter processes on the juxta than in N. fasciella (Fig. 4). There are also fine differences in the structure of the transtilla of the tegumen and in the shape of the vinculum (WOJTUSIAK 1972, RAZOWSKI 1978). The female genitalia of the two species do not differ in any unequivocal way; they were not analysed in the present study.

\section{DISTRIBUTION}

According to "Fauna Europaea", N. prodigellus has so far been recorded from Spain, France, Italy, Switzerland, Germany, Austria, Albania, Macedonia, Romania, Hungary, Slovakia, the Czech Republic and the central part of European Russia (KozLov 2004, KARShOlt \& NieUKerken 2013). Besides the historical record from the Polish Carpathians, RAZOWSKI (1978) gave the origin of the male illustrated on plate 10 (No. 5) and Fig. 348 as "Krzywcze" (see the list of Figure captions). This locality, formerly in the historical region of Galicia, is now identified as Krivče (Ukr. Кривче) in the Tarnopol district (Ternopilśka obłast - Ukr. Тернопільська область). The species should thus be treated as having been recorded in Ukraine in the period 1918-1939 (Fig. 6). The species was not listed in KREMKY's (1937) faunistic study of the Podole region, because it covered only the so-called Macrolepidoptera. In the Czech Republic the species is known only from Moravia (LAŠTUVKA et al. 1998), so it may well have been overlooked in the central and eastern Sudeten Mts. From the faunistic point of view it is new to the province of Lower Silesia (which includes the Sudeten Foothills). 


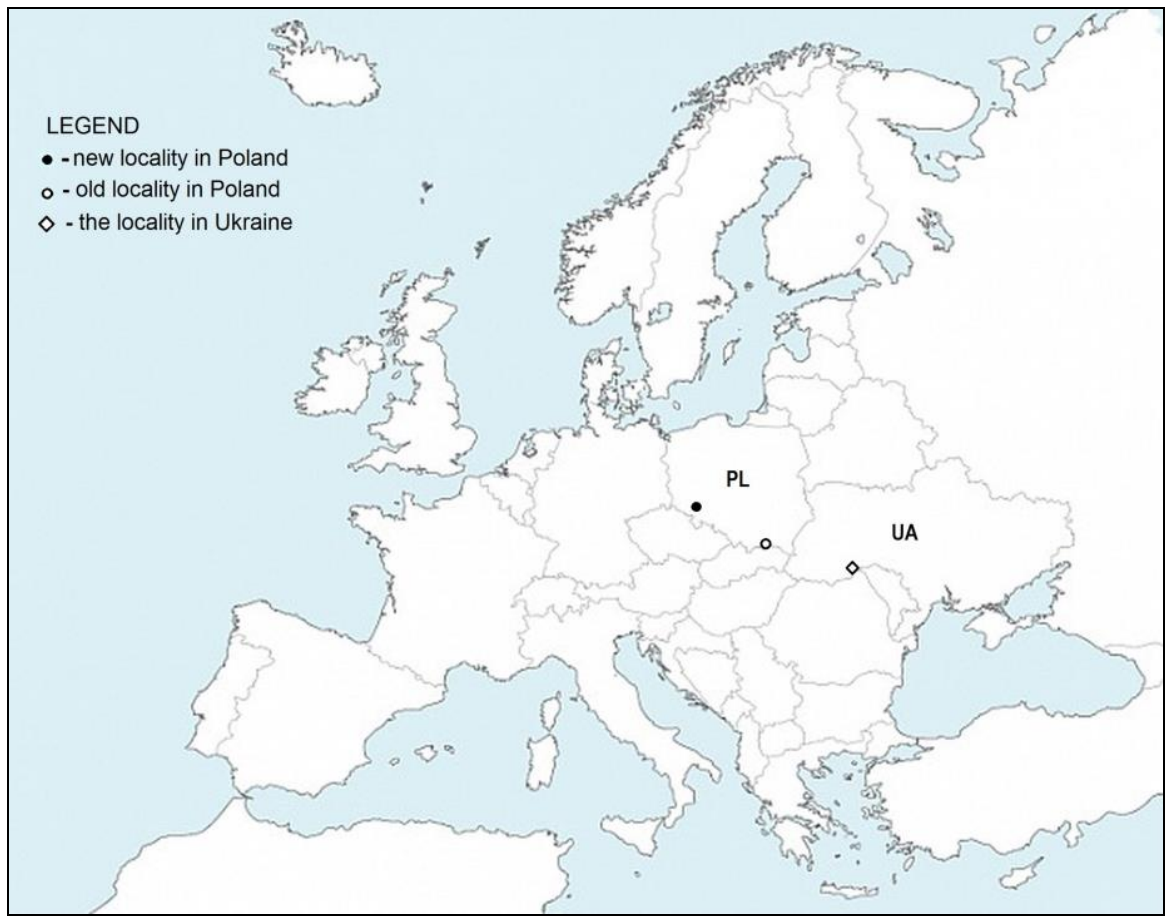

Fig. 6. The localities of Nemophora prodigellus in Poland (PL) and Ukraine (UA).

\section{BIOLOGY}

The species is univoltine, the flight period being from mid-June to late July. The caterpillars live solitarily in flowers of Stachys officinalis. The biology and morphology of the immature stages and imagines from the canton of Bern (Switzerland) have been described and illustrated in detail by Rudolf BRYNER: http://www.lepiforum.de/ lepiwiki.pl?Nemophora_Prodigellus.

The female places the eggs singly onto the flower buds of the hostplant. The young caterpillars feed on the pistils, filaments and ovaries of the flowers. After the flowers have withered, the caterpillars live under the leaves of their host plant and from below the leaves eat holes in them. The first larval case is then constructed from a cleaned out flower. The third larval phase (from autumn to the following spring) takes place at ground level, on the lowest leaves of Stachys officinalis plants. The caterpillar builds its final flat, brown case, from two halves, like the shell of a mussel, both with convex sides. In such a shelter the larva moves, forages, hibernates and ultimately pupates. Before pupation the caterpillar 
buries itself in loose sand on the ground, after having spun all kinds of mineral and plant particles to the case.

\section{HABITAT REQUIREMENTS AND THREATS}

Nemophora prodigellus is probably the very last or among the last in the species assemblage typical of the abandoned hay meadow plant association (Molinietum medioeuropaeum КосH 1926; others from Class Molinio-Arrhenatheretea), endangered both in Lower Silesia and in Poland as a whole (KACKI et al. 2003, MichaLSKA-HEJDUK 2012). There are historical records from the "Ląka Sulistrowicka" Nature Reserve and nearby meadows of Lepidoptera: Trifurcula beirnei PUPLESIS, 1984, Ectoedemia viridissimella (CARADJA, 1920), Stigmella filipendulae (WOCKE, 1871), Glaucopsyche alexis (PODA, 1761), Phengaris alcon (DENIS et SCHIFFENMÜLLER, 1775), Phengaris teleius (BERGSTRÄSSER, 1779), Euphydryas aurinia (ROTTEMBURG, 1775) and Minois dryas (SCOPOLI, 1763) [from the Ślęża Massif]. Most of these species are now extinct in this locality. One or two may have survived, but their populations will have fallen significantly. The situation regarding the plants characteristic of this type of meadow and to some degree also the hostplants and foodplants of butterflies and moths may soon be similar. The locality of Nemophora prodigellus is a very valuable part of a Molinia meadow (Natura 2000 Habitats Directive code 6410), which is one of the best formed patches of this habitat in Lower Silesia, fully comparable with the similar meadows protected in the "Eąka Sulistrowicka" reserve and deserving of being protected as a separate entity (Fig. 7, 8). Among the plant species characteristic of habitat type 6410, there are numerous populations of the following on this meadow: Iris sibirica L., Stachys officinalis, Serratula tinctoria L., Potentilla alba L., Succisa pratensis MNCH., Selinum carvifolia L., Molinia caerulea (L.), Galium boreale L., Inula salicina $\mathrm{L}$., as well as other species frequently present in this kind of habitat, like Galium verum L., Trollius europaeus L., Carex flava L., Carex panicea L., Potentilla erecta (L.) HAMPE, Lysimachia vulgaris L., Salix rosmarinifolia L. and Polygonum bistorta L. They are accompanied by lowland hay meadow (habitat 6510) species (e.g. Poa pratensis L., Festuca rubra L., Arrhenatherum elatius (L.), Leucanthemum vulgare LAM.; some of the meadow is gradually becoming overgrown with trees and shrubs because it was not regularly mown in the past (Fig. 8).

The degradation of plant diversity and plant structural composition entails an impoverishment of the lepidopteran species composition. This is the main problem affecting the management and protection of abandoned hay meadows in Central Europe, wherever their ownership is not clear and also where the conservation measures hitherto applied have failed in their aim, as in the case of the strictly protected, i.e. passively 
conserved, "Ląka Sulistrowicka". This meadow should have been extensively utilized in order to prevent the spontaneous succession of woodland. Another harmful factor, the impact of which has been growing in recent years, relates to invasive, alien plants, which are encroaching on to native plant associations rather quickly, and the no less dangerous, native expansive plant species (KADEJ et al. 2014). These species most often appear in unused or disturbed habitats, such as meadows, and are generally manifestations of the ongoing succession of the vegetation, e.g. the transformation of meadow vegetation into woodland. This expansion is due, among other things, to intensive seed production and/or very rapid proliferation via a system of underground rhizomes. The best example of this is the expansion of Calamagrostis epigejos (L.) ROTH, observed in the habitat of $N$. prodigellus (Fig. 8).

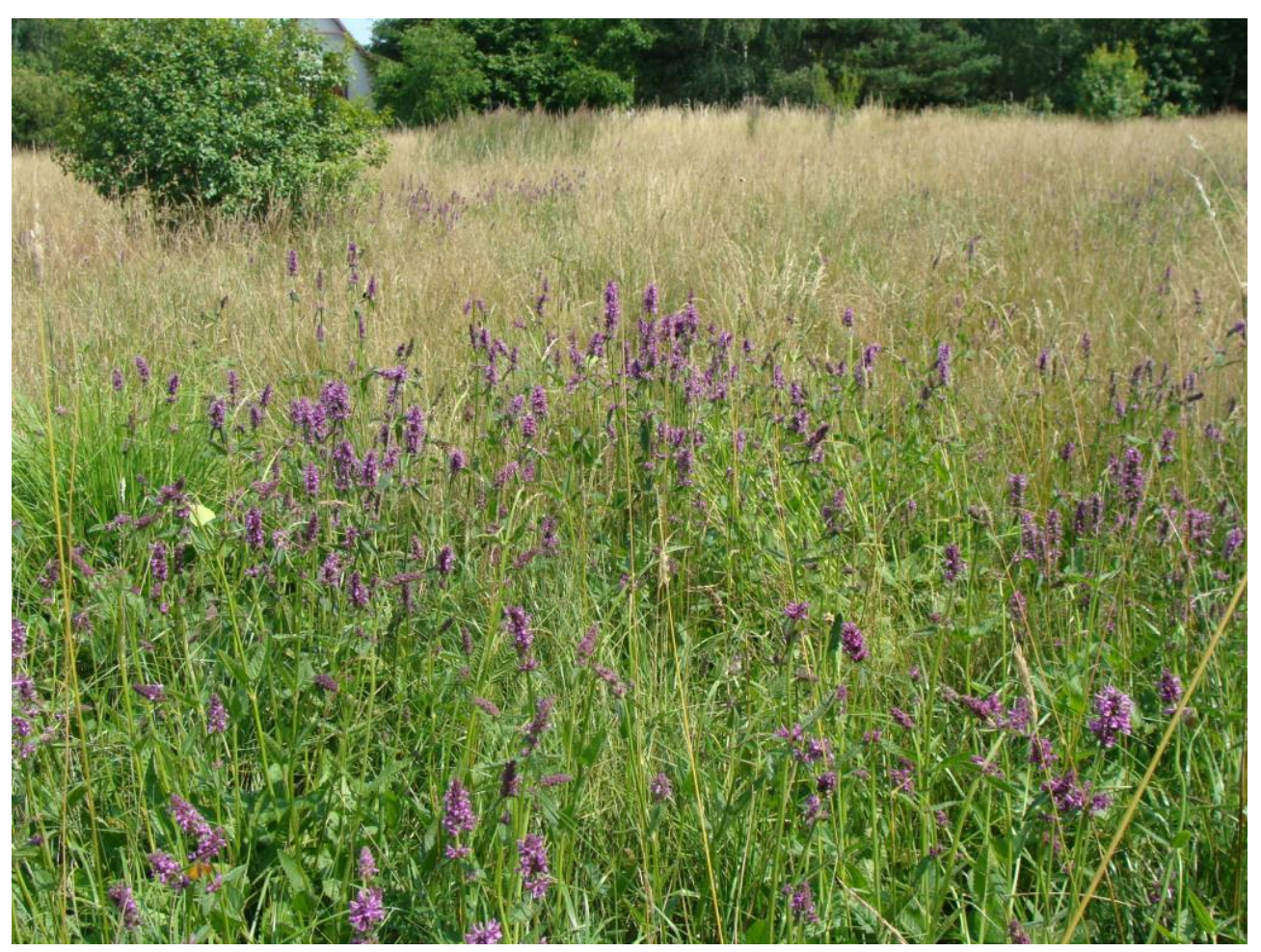

Fig. 7. Habitat of Nemophora prodigellus - Sulistrowiczki (VII 2015), the patch dominated by Stachys officinalis, the hostplant. Photo A. MALKIEWICZ. 


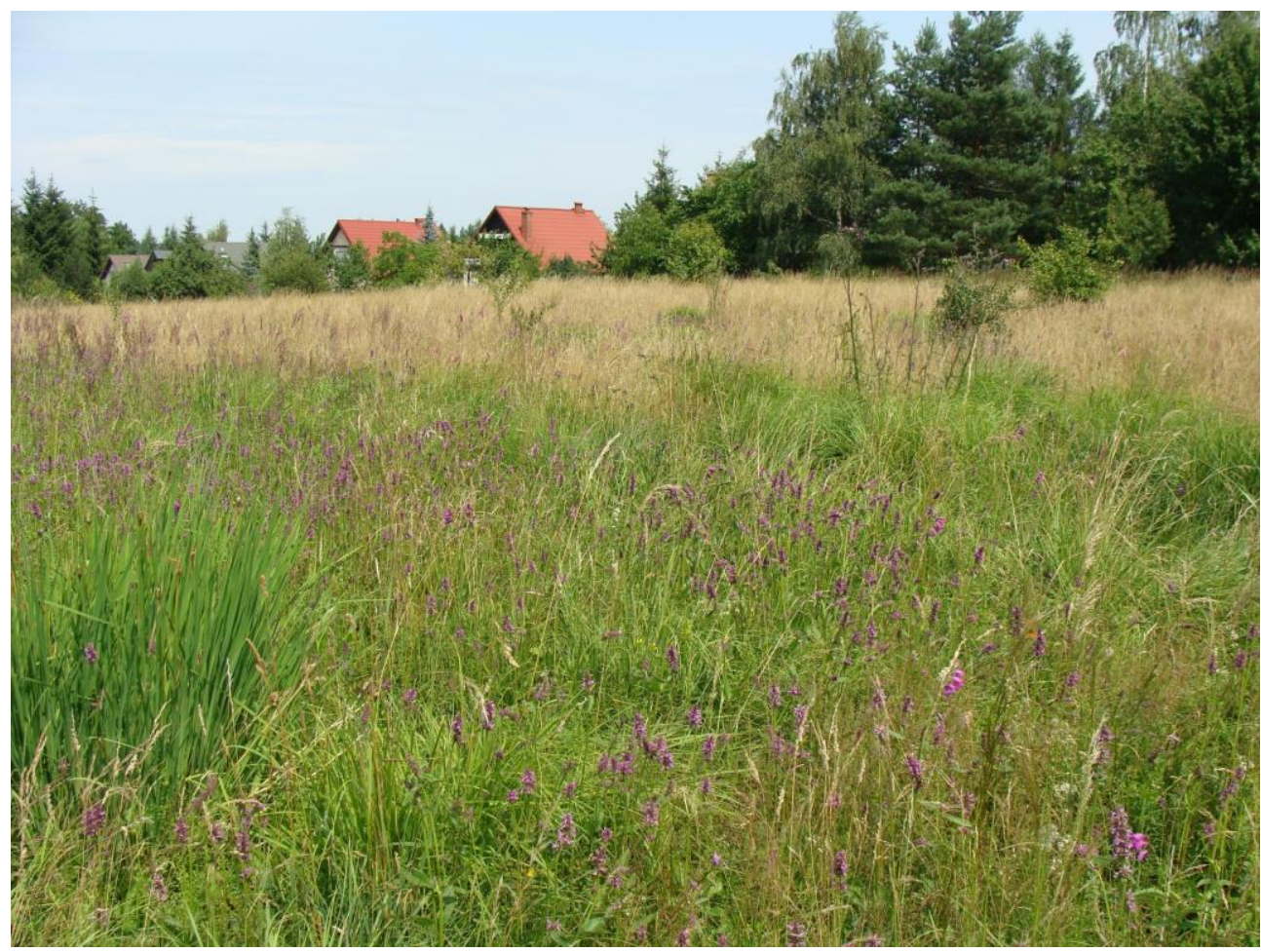

Fig. 8. Habitat of Nemophora prodigellus - Sulistrowiczki (VII 2015): the effect of succession on a Molinia meadow. Photo A. MALKIEWICZ.

The main threats to the „Ślęża Massif” are as follows: the uncontrolled, increasing pressure from recreation and tourism; tourist infrastructure and the increasing amounts of litter and rubbish left in the area; forest management practices that ignore the specific requirements of some woodland habitats; the trampling and despoliation of Molinia meadows (6410); the falling water table as a result of water being drawn for the use of the local communities, which causes the Molinia meadows to dry out; the overgrowth of species-rich Nardus grasslands (6230) resulting from their not being mown or grazed; the trampling of xerothermic grasslands where tourist pressure is particularly intense; eutrophication; the invasion of synanthropic species like Small Balsam Impatiens parviflora DC., Douglas Fir Pseudotsuga menziesi (MIRB.), False-acacia Robinia pseudoacacia L. and Black Cherry Prunus serotina (ERHR) BORKH. (ŚWIERKOSZ 2013). 


\section{REFERENCES}

Buszko J., Nowacki J. 2000. The Lepidoptera of Poland. A Distributional Checklist. Polish Entomological Monographs, 1. Polskie Towarzystwo Entomologiczne, Poznań.

Kadej M., Malicki M., Malkiewicz A., Smolis A., Suchan T., Tarnawski D. 2014. Permanent protection of endangered habitats and butterflies in the Nature 2000 network in southwestern Poland. Stowarzyszenie Ekologiczne EKO-UNIA, Wrocław. (in Polish)

KĄCKI Z., DAJDOK Z., SZCZĘŚNIAK E. 2003. Red list of vascular flora of Lower Silesia. [in:] Z. KĄCKI (ed.). Thretatened species of vascular plants of Lower Silesia. Instytut Biologii Roślin Uniowersytetu Wrocławskiego, Polskie Towarzystwo Przyjaciół Przyrody „pro Natura”, Wrocław, 9-65. (in Polish)

KARSholt O., NieuKERKEN E.J. van 2013. Lepidoptera, Moths. Fauna Europaea version 2.6. Internet: http://www.fauna-eu.org.

Kozlov M.V. 2004. Annotated checklist of the European species of Nemophora (Adelidae). Nota Lepidopterologica 26(3/4): 115-126.

Kremky J. 1937. Études sur la faune des Lépidoptères de la Podolie Polonaise. 1. Fragmenta Faunistica Musei Zoologici Polonici 3(11): 81-217. (in Polish)

LaštuVka Z., Elsner V., Jaroš J., Laštuvka A., LišKa J., Marek J., Skyva J. 1998. Checklist of Lepidoptera of the Czech and Slovak Republics (Lepidoptera). Konvoj, Brno.

MichaLSKA-HeJduK D. 2012. 6410 Molinia meadows with fluctuating humidity (Molinion). [in:] Monitoring of species and natural habitats, with particular focus on the Special Areas of Conservation Natura 2000. Results of the monitoring. Internet: http://siedliska.gios.gov.pl/pdf/ siedliska/2009-2011/wyniki_monitoringu_siedlisk_6410.pdf. (in Polish)

RAZOwSKi J. 1978. Lepidoptera of Poland. Part III - Heteroneura, Adeloidea. Monographs of the fauna of Poland, vol. 8. PWN, Warszawa - Kraków. (in Polish)

SCHILLE F. 1902. Lepidopterological fauna of the valley of the River Poprad and its tributaries. Part IV. Sprawozdania Komisji Fizyograficznej 36: 36-39. (in Polish)

SCHILLE F. 1914-1915. Micromoths of Galicja (Microlepidoptera Haliciae). Kosmos, ser. A 39: 519598; 40(1-6): 141-179. (in Polish)

SChILLE F., RomaniszYn J. 1931. Fauna Lepidopterorum Poloniae. 2. Monographic publications of the Physiographic Committee, vol. 7. Polska Akademia Umiejętności, Kraków.

ŚwIERKosz K. 2013. Ślęża Massif. Special Area of Conservation Natura 2000 PLH020040. [in:] K. ŚwierkosZ, K. ZAJĄC, H. LIBERACKA, M. ŁySIAK (eds.). Natura 2000 aeras in Lower Silesia. Regionalna Dyrekcja Ochrony Środowiska we Wrocławiu, Wrocław, 190-193. (in Polish)

Wojtusiak J. 1972. Adelidae. Keys for the identification of Polish insects, Part XXVII, issue 9. PWN, Warszawa. (in Polish)

Received: 18 March 2016

Accepted: 4 May 2016 